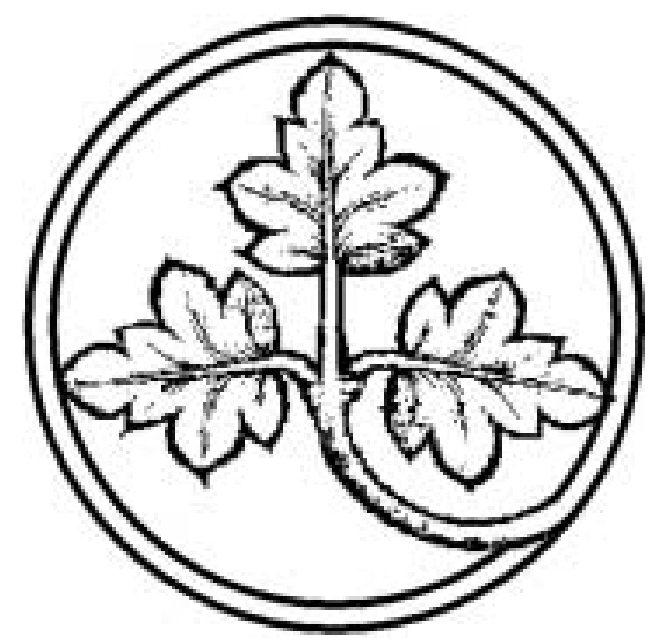

Gemeinschaftsgüter: Recht, Politik und Ökonomie

Preprints
aus der Max-Planck-Projektgruppe
Recht der Gemeinschaftsgüter
Bonn
$2001 / 8$

Hybrid Governance Across National Jurisdictions as a Challenge to Constitutional Law

Von

Christoph Engel 


\title{
Hybrid Governance Across National Jurisdictions as a Challenge to Constitutional Law
}

\author{
Christoph Engel
}

July 2001

Max-Planck-Projektgruppe Recht der Gemeinschaftsgüter, Poppelsdorfer Alle 45, 53115 Bonn

www.mpp-rdg.mpg.de 


\section{Hybrid Governance Across National Jurisdictions as a Challenge to Constitutional Law}

\section{Introduction}

A technology often reaches perfection when its successor is already in place. Miraculously speedy and reliable punch card readers were finally available on the market when demand shifted to personal computers, to cite only one example. Do constitutions follow the same evolutionary pattern? Constitutional law, in general, and the doctrine of fundamental freedoms, in particular, are in admirable shape. Their dogmatics have been amply tested; they are elegant and rich. But they have been developed for the nation state. Yet governance reality is increasingly different. The state is competing with foreign, international and private governing authorities, or it is joining them in hybrid efforts. Will de-constitutionalisation ensue? Or will the existing constitutions be able to face, or even alter, the new reality?

This is a paper about governance. Hardly a term is more disputed in the social sciences ${ }^{1}$. This paper looks at (potentially) global, not national or European governance. It therefore cannot avoid using the broadest of all possible definitions of governance. Since on the global scale there is no such thing as a widely undisputed higher order system, the term governance must comprise all modes of social ordering, by whatever actor or actor configuration ${ }^{2}$.

The focus of this paper is on divergent governance bodies, not governance tools. It does not want to explore whether the pertinent body uses (quasi-)legal rules, incentives, moral suasion or any other tool for governing the behaviour of its addressees. It simply looks at who purports to change the behaviour of a class of addressees, in the alleged interest of some protectees.

Moreover, when it speaks of governance, the paper exclusively looks at intentional attempts to change the behaviour of addressees. The limitation inherent in this becomes clear when looking at a constitutional court. To the extent that it has jurisdiction one can interpret such a court as the supreme legal authority. At the limit, the court can even overrule the legislator. But, strictly exceptional instances notwithstanding, a constitutional court does not itself write the law. It at most invalidates existing rules, or gives them a different meaning. In both cases, parliament remains the governing body.

1 A coherent overview of competing definitions, and how they have evolved, is to be found in Mayntz, R., N ew Challenges to G overnance Theory (Florence: European University Institute, 1998, The Robert Schuman Centre, Jean Monnet Chair Papers 50).

2 Id. 18 s., see also 16 
Finally, this is an interdisciplinary paper in that it draws on insights from the social sciences, and from political sciences in particular. But it does so exclusively in the interest of better understanding a dogmatic problem of constitutional law: how can and how should a national constitution react when governance activities cannot (exclusively) be attributed to the governance bodies created by the constitution ? More specifically even, the paper does not intend to design the appropriate reaction for a concrete instance of not exclusively public national governance. Its goal is much more modest. It wants to provide constitutional lawyers with a conceptual framework for addressing such concrete design problems. This explains why the paper does by far not exploit the richness of the discussion on hybrid international governance in the political sciences ${ }^{3}$.

The following sketch purports to address these questions from the angle of the German constitution. It starts with a taxonomy of governance authorities (II). It briefly summarizes the normative arguments for and against international, private and hybrid governance (III). It points to the option of privatising, internationalising and hybridising the constitution itself (IV), but focuses on strategies for the existing national constitutions in the face of an altered reality (V). The concluding dogmatic treatment is confined to fundamental freedoms. It starts by isolating the international (VI) and the private dimension (VII), then goes on to address the more complex private international (VIII) and hybrid forms of governance (IX).

\section{A Taxonomy of Governance Bodies}

The basic forms of governance bodies are contained in the following figure:

\begin{tabular}{|c|c|}
\hline $\begin{array}{l}\text { private- } \\
\text { national }\end{array}$ & \\
\hline $\begin{array}{l}\text { semi- } \\
\text { public }\end{array}$ & hybrid \\
\hline $\begin{array}{l}\text { public- } \\
\text { national }\end{array}$ & $\begin{array}{c}\text { semi- } \\
\text { national }\end{array}$ \\
\hline
\end{tabular}

3 Out of the rich literature see on the public/ private divide in particular Streeck, W., Schmitter Ph.C. (eds.), Private Interest G overnment. Beyond Mark et and State (London: Sage, 1985); Streeck, W. (ed.), Staat und Verbände, special issue 25 of Politische V iertejahresschrift 35 (1994) 1-401.

On the international dimension see in particular Hasenclever, A., Mayer, P., Rittberger, V., Theories of International Regimes (Cambridge Studies in International Relations 55, Cambridge: Cambridge University Press, 1997); Hewson, M., Sinclair, T.J. (eds.), A pproaches to G lobal G overnance Theory (New York: State University of New York Press, 1999). 
Public-national governance is the classic form of state governance. An example of public-foreign governance is the extraterritorial application of US antitrust law to a merger of two German firms (because they do business on the US market, for instance) $)^{4}$. Private national governance is exercised by the German Green D ot organisation. Its prime business is price regulation for the disposal of packaging waste ${ }^{5}$. The electronic tools used by AOL are one example of private foreign governance. They are meant to prevent children from accessing all websites that it does not deem "familyfriendly" ${ }^{\prime \prime}$, and to prevent spammers from reaching the AO L audience? ${ }^{7}$.

Each of the dimensions is a scale. In semi-national cases, the German government has at least some influence on a transnational governing body. In semi-public cases, government has at least some influence on a not-fully-public governing body. In both cases, the influence can stem from the delegation of governance powers, from membership, from legal supervisory authority, from legal or factual threat power, or from the governing body's interest in incorporating its output into state law. The private and the foreign dimensions can be combined. The two dimensions thus open up a space for hybrid governance authorities.

\section{Normative Arguments}

National constitutions are basic charters for public-national governance. This simplifies the constitutional discourse. The normative problem is not an open choice among alternative governance authorities. The constitutionalist needs a justification for moving away from the normal public-national governance. The constitution assumes that this govemance authority has struck the right balance between competing constitutional concerns.

The basic reason for accepting, fostering or demanding an alternative governance authority is the expectation that there will be a greater problem-solving capacity. It can derive from the nature of the policy problem, from the power structure beyond the reach of the national constitution, from a comparison of regulatory cost, or from overriding normative concerns about the available public regulatory options.

4 More on the extraterritorial application of national public law from Schnyder, A.K., W irtschattsk ollisionsrecht. Sonderanknüpfung und extraterritoriale A nwendung wirtschaftsrechtlicher Normen unter besonderer Berücksichtigung von Mark trecht (Zürich: Schulthess, 1990); Meng, W., Ex traterritoriale Jurisdik tion im öffentlichen W irtschaftsrecht (Berlin: Springer, 1994).

5 This is not obvious at first sight, for the details see Lehmann, "Private Institutions in Waste Management Policy and Their Antitrust Implications. The Case of Germany's Dual Management System", Preprints aus der Max-Planck-Projek tgruppe Recht der G emeinschaftsgüter Bonn: 1999/ 13.

6 http:/ / www.aol.com/ info/ onlinesafety.html (04-23-2001).

7 http:/ / www.aol.com/ info/ bulkemail.html (04-23-2001). 
International governance is natural if the policy problem has transnational reach. Nation states are not helpless then. They, in particular, can apply their own rules beyond the boundaries of their own territory. But transnational bodies may be more effective, more elegant or cheaper. Globalisation is transnationalising many policy problems that have previously been purely national. Likewise, governance that is not purely public is natural if the policy problem has to address the selfreferentiality of social sub-systems ${ }^{8}$. Again, the constitution is not helpless. It can strive to bring private governance "under the shadow of hierarchy" ${ }^{\prime}$. In the more theoretical terms of systems theory, it can increase the resonance of the sub-system for public governance attempts, or even destroy its autonomy ${ }^{10}$. But the constitution may not want either of these stategies, or these strategies may seem too costly. Moreover in both dimensions, there may be a value in openness. It triggers regulatory competition, which can be an evolutionary advantage and can help control interested policy makers ${ }^{11}$. Finally, hybrid governance can help overcome conflict among nations, or between the governance body and the social actors who hold veto positions ${ }^{12}$.

Hybridisation engenders constitutionally relevant $\operatorname{costs}^{13}$. It weakens the democratic legitimation of governance and judicial control. It loosens the protection of minorities and individuals. It circumvents organisational and procedural checks and balances. It results in a less clear separation between law and politics, which in turn leads to partial de-differentiation ${ }^{14}$. Hybrid bodies usually have narrowly limited authority. They can become single-issue constituencies ${ }^{15}$. It becomes difficult to link issues. Veto-positions are harder to overcome ${ }^{16}$. Social conflict is more likely. D isintegration is possible ${ }^{17}$. There is also a risk of over-fitting ${ }^{18}$, which is an evolutionary drawback. Once hybrid governance is accepted in principle, interested actors can strategically increase the degree of such

8 Basic (and sceptical) Luhmann, N., Ökologische Kommunikation (Opladen: Westdeutscher Verlag, 1986); (mildly optimistic) Teubner, "Privatregimes: Neo-Spontanes Recht und duale Sozialverfassungen in der Weltgesellschaft?", in Z ur A utonomie des Individuums, Liber A miorum Spiros Simitis, eds. Simon/ Weiss (BadenBaden: Nomos, 2000), 437-453.

9 Using the famous term dubbed by Scharpf, F., Games Real A ctors Play. A ctor-C entred Institutionalism in Policy Research, Boulder: Westview 1997, 22 and 138 s.

10 More from Teubner, supra note 8.

11 O ut of the rich literature see only Gerken, L. ed., Competition A mong Institutions (Houndmills: Macmillan, 1995); Monopolkommission, Sondergutachten 27, Systemwettbewerb (Baden-Baden: Nomos, 1998); Müller, Markus, Systemwettbewerb, $\mathrm{H}$ armonisierung und W ettbewerbsverzerrung (Baden-Baden: Nomos, 2000).

12 Cf. Der Wissenschaftliche Beirat beim Bundesministerium für Wirtschaft, "Aktuelle Formen des Korporatismus", in G utachten vom F ebruar 1998 bis Juli 2000 (Stuttgart: Lucius, 2000), 2077-2103.

13 More on the following from Engel, "Institutionen zwischen Staat und Markt", D ie V erwaltung 34 (2001): 1-24 (18-24).

14 Luhmann, supra 8, 218-226 and passim.

15 Cf. Roemer, "A Theory of Policy Differentiation in Single Issue Electoral Politics", Social Choice and W elfare 11 (1994): 355-380.

16 The concept has been developed by Immergut, E., H ealth Politics. Interests and Institutions in Western E urope (Cambridge: Cambridge University Press, 1992).

17 The classic legal text on integration theory is Smend, R., V erfassung und V erfassungsrecht (Munich: Duncker \& Humblot, 1928).

18 On over-fitting, see e.g. Geman, Bienenstock and Doursat, "Neural Networks and the Bias/Variance Dilemma", N eural Computation 4 (1992): 1-58. 
governance. All this can be addressed as partial de-constitutionalisation. The constitution looses control over governance activities. The distinction between an ordinary and the constitutional level of law gets partially blurred. In the extreme case, governance boils down to what the governance body can do without running the risk of overthrow.

\section{Hybridising the Constitution, Constitutionalising Hybrid Governance?}

A radical reaction to the diffusion of hybrid governance bodies would be to hybridise the constitution itself, or to constitutionalize international, private and hybrid governance. Constitutionalisation of a governance body means that its actual governance activities are bound by rules on organisation, procedure and substance that are not at the disposition of the body itself, at least not on an ad hoc basis and using its ordinary procedure.

The idea of constitutionalising private, international or hybrid governance is becoming increasingly popular. Public international lawyers have called for the constitutionalization of their field ${ }^{19}$, as have European Community lawyers ${ }^{20}$. Human rights and other humanitarian rules of public international law go even further and claim authority over national action that has no international element. A forteriori they do apply to semi-national governance. Constitutionalizing (semi-)private governance is not discussed in these terms. But in essence this is the solution to the U.S.-E.U. conflict over data protection. Under European pressure, the FTC is being turned into a supervisory authority for private self-governance ${ }^{21}$.

The contrasting concept rest on legally incorporating (semi-)private or (semi-)foreign bodies into the national constitution. Theoretically, this could be done without hybridising the constitution. The private or foreign body would then become an exceptional organ of the constitutionalised order of a country. The technical legal term characterises the idea: the constitutional order would "borrow" an institution from another legal entity. But this is hardly ever a practical option. For it would fully bring the borrowed institution under the jurisdiction of the borrowing legal order and its constitution. The institution would have to fully play by these constitutional rules. The legal entity of origin will normally not be willing to accept such alienation. If however the legal order of destination foregoes full legal control over the inserted governance body, hybridisation of the constitution

19 Programmatic Frowein, "Konstitutionalisierung des Völkerrechts", Berichte der D eutschen Gesellschaft fur V ölk errecht 39 (1999): 427-448.

20 Comprehensive V eröffentlichungen der V ereinigung der D eutschen Staatsrechtslehrer 60 (forthcoming).

21 Farrell, "Negotiating Privacy in the Age of the Internet - Analysing the EU-US 'Safe Harbor' Negotiations", in Common $\mathrm{G}$ oods and $\mathrm{G}$ overnanœ A cross M ultiple A renas, ed. Héritier, A., (forthcoming). 
ensues. The constitution legalises governance activities, although they are legally not fully under its control.

But hybridising the constitution and constitutionalizing hybrid governance are, at best, incubating concepts. It will take a long time before they can give adequate guidance and satisfactory legal certainty. Due to the hybrid element, they will never be able to address some of the constitutional concerns, like disintegration. In all likeliness, national constitutions will not disappear in the process. They will still want to have an impact on private, international and hybrid governance bodies. At the very least, the threat of unilateral constitutional action will spur the process of constitutional hybridisation ${ }^{22}$.

\section{Strategies for the National Constitutions}

Vis-à-vis private, international and hybrid governance bodies, national constitutions basically have three strategic options: forbearance, mitigation and adaptation.

Forbearance is a passive strategy. The constitution allows governance even where it has no or limited influence. If it opts for this, the constitution must make sure that its own normativity is not eroded. Two lines of argument can help: compensation and encapsulation. Compensation stresses the fact that the outside regulator has indeed constitutionalized itself. It demonstrates that the level of protection is similar to that offered by the national constitution, or at least adequate, given the type of action. The G erman Constitutional Court has basically relied on this strategy with respect to the European Union ${ }^{23}$.

Encapsulation presupposes that constitutional standards are only deviated from in exceptional cases, which are, for obvious reasons, beyond the reach of the constitution. The German Constitutional Court has used this strategy two times: in the Saar ${ }^{24}$, and in the Second Register for Vessels case ${ }^{25}$. In the first case, it pointed to post-war conditions, in the second to the fully global character of sea transportation. The problem with encapsulation is constructivist: will the public accept the exceptional character (or just overlook the cases)?

22 A graphic example of the strategy is the Maastricht judgement of the German Constitutional Court. It in essence means that the German court threatens the European Court of Justice, i.e. that it will apply German fundamental rights to European legislation, should the autonomous European fundamental rights appear grossly unsatisfactory, BVerfG E 89, 155.

23 See again BV erfG E 89, 155.

24 BVerfGE 4, 157.

25 BVerfGE 92, 26. 
Mitigation is a defence strategy. The constitution strives to immunise national public regulation from the effects of regulatory competition, or to attenuate its effects ${ }^{26}$. 0 ccasionally mitigation is nearly impossible. This is the central argument of the Constitutional Court in the Second Register for Vessels case. Vessels travelling over the oceans can be registered everywhere in the world. A single regulatory haven is enough to make co-operative efforts to keep the standards up futile. Mitigation is often costly, especially in terms of opportunity costs, i.e. foregone benefits. And not all effective defence techniques are normatively acceptable for the constitution. Putting foreigners into jail because their country of origin engages in unfair regulatory competition is an obvious example.

Adaptation can be either conceptual or real. Conceptual adaptation closes the gap between the constitutional standard and regulatory reality by lowering the standard. Occasionally the private or international challenge teaches the constitution that it had overlooked or not properly balanced a true concern. European administrative law might have such an effect in that it helped the German constitution find a proper dogmatic place for administrative efficacy ${ }^{27}$. More often, constitutional standards can and should be differentiated. If a person voluntarily goes abroad or engages in international trade, he deserves less constitutional protection ${ }^{28}$. If a case lies partly or even fully outside the reach of $\mathrm{German}$ sovereignty, the constitution has less responsibility for $\mathrm{it}^{29}$. If the individuals, or at least the group to which they belong, have viable tools to protect themselves ${ }^{30}$, the constitution might accept less public protection.

Real adaptation means partly redesigning the constitution. This is what hybridising the constitution is about. But it can come in small steps. One example is the Maastricht decision of the Constitutional Court. The court claims jurisdiction for the testing of secondary Community law against German fundamental freedoms. But it claims to do so "in co-operation" with the European Court of Justice ${ }^{31}$. In practical terms, this makes constitutional complaints a fall-back position for German nationals who feel that the European Court of Justice has not given them adequate protection.

26 For an overview of dogmatic avenues to be used for the purpose see Engel, "Legal Experiences of Competition among Institutions, in Competition among Institutions, ed. Gerken, L. (Houndmills: Macmillan, 1995) 89-118.

27 Comprehensive Rengeling, "D eutsches und Europäisches Verwaltungsrecht - Wechselseitige Einwirkungen", $\mathrm{V}$ eröffentlichungen der V ereinigung der D eutschen Staatsrechtslehrer 53 (1994): 202-239.

28 Although the dogmatic consequences derived from the idea are too strong in Elbing, the idea is to be found in Elbing, G., Zur A nwendbark eit der G rundrechte bei Sachverhalten mit A uslandsberührung (Berlin: Duncker \& Humblot, 1992): 317.

29 Cf. id. 190.

30 The idea is offered by Dam, K.W., Self-H elp in the D igital Jungle (Chicago: John M. Olin Law \& Economics Working Paper 59, 1998).

$31 \quad$ BV erfGE 89, 155, Leitsatz 7. 
Forbearance and conceptual adaptation do not involve redesigning rules. Mitigation and real adaptation do. The constitution basically has four options. It can control the formation of private, international or hybrid regulatory bodies. It can control their output. It can influence the outcomes of their regulatory activities by controlling their effects within the German territory or on German nationals ${ }^{32}$. And it can compensate the victims for deviations from the German constitutional standards, be that in money or in kind.

\section{Fundamental Freedoms and International Governance}

The constitutional dogmatics of international governance have a formal and a substantive dimension. The formal dimension addresses regulatory organisation and procedure ${ }^{33}$. The substantive dimension addresses regulatory content. The following observations are confined to the core of the substantive dimension, fundamental freedoms.

Adapting fundamental freedoms to international governance is an old problem ${ }^{34}$. The dogmatics for addressing it are relatively well-developed. They start by asking whether the respective governance act can be attributed to an entity that is passively legitimated by the fundamental freedoms of the German constitution ${ }^{35}$. Passive legitimation means that the fundamental freedoms directly bind the entity $^{36}$. This is obvious for the government and any autonomous public entity, such as the L änder or the municipalities. Traditional wisdom was that social actors were not directly bound by fundamental freedoms; the freedoms had no third-party effects, to use the common jargon ${ }^{37}$. At most, government was constitutionally obliged to protect one individual against the intrusions of other individuals into his constitutionally protected sphere ${ }^{38}$. The Maastricht decision of the Constitutional Court might haven broken with this tradition, however. For the German fundamental freedoms are now directly applied to secondary Community law, because it applies legally within the domain of the $\mathrm{G}$ erman constitution ${ }^{39}$. Along the same lines one could argue that private governance

32 The distinction between outputs and outcomes is basic in implementation research of political scientists, see Windhoff-Héritier, A., Politik implementation (Königstein: Hain, 1980), 5 and passim.

33 On attempts to reach substantive regulatory aims by affecting the organisation or procedure see Engel, "Regulierung durch Organisation und Verfahren", in F estschrift für E rnst-Joachim Mestmädker, eds., Immenga, Möschel and Reuter (Baden-Baden: Nomos, 1996), 119-138.

34 Besides Elbing, supra note 28, see Hofmann, R., G rundrechte und grenzüberschreitende Sachverhalte (Berlin: Springer, 1993); Kronke, "Die Wirkungskraft der Grundrechte bei Fällen mit Auslandsbezug", Berichte der D eutschen G esellschaft fur V ölk errecht 38 (1998): 33-67.

35 Elbing, supra note 28, 190. Comprehensive Stern, K and M. Sachs, Staatsrecht III/ 1 (München: Beck, 1988), 1511 ss. Dietlein, J., D ie L ehre von den grundrechtlichen Schutzplichten (Berlin: Duncker \& Humblot, 1992). BVerfGE 89, 155, Leitsatz 7: "Auch Akte einer besonderen, von der Staatsgewalt der Mitgliedstaaten geschiedenen öffentlichen G ewalt einer supranationalen O rganisation betreffen die Grundrechtsberechtigten in 
comes under direct constitutional scrutiny, once the legal order in principle acknowledges its legal validity.

Governance can be attributed to the German government if it has legally delegated regulatory authority to an international body ${ }^{40}$; if the government has participated in the rule-making activity ${ }^{41}$; probably also, if it had membership rights without using them; and if it has autonomously incorporated the foreign regulatory output into the G erman legal order ${ }^{42}$.

The dogmatic technique for encapsulation is known as "closer to" jurisprudence. Open deviations from substantive constitutional standards are accepted if the constitution would otherwise have to accept an outcome that is even worse ${ }^{43}$. The Saar would otherwise have remained under French occupation ${ }^{44}$; almost all vessels would otherwise have registered under foreign flag ${ }^{45}$. The outside pressure, which $\mathrm{G}$ ermany alone would not be able to quash or parry, is decisive here.

Conceptual adaptation fully uses the dogmatics of fundamental freedoms. Foreign nationals are not protected at all by some freedoms (like freedom of commerce), and not fully by others ${ }^{46}$. Transnational cases are not protected by some freedoms (like freedom of movement), and not fully by others ${ }^{47}$. If the German government has only had an indirect impact on international regulatory activities, this might not be enough to justify interference with the respective fundamental freedom.

Deutschland. Sie berühren damit die Gewährleistungen des Grundgesetzes und die Aufgaben des Bundesverfassungsgerichts, die den Grundrechtsschutz in Deutschland und insoweit nicht nur gegenüber deutschen Staatsorganen zum Gegenstand haben (Abweichung von BVerfGE 58, 1 (27)). Allerdings übt das Bundesverfassungsgericht seine Rechtsprechung über die Anwendbarkeit von abgeleitetem $\mathrm{G}$ emeinschaftsrecht in Deutschland in einem ,Kooperationsverhältnis' zum Europäischen Gerichtshof aus"; literally the same sentences are to be found at BVerfGE 89, 155, 175; there the passage ends with " $[. .]$, ,Kooperationsverhältnis' zum Europäischen Gerichthshof aus, in dem der Europäische Gerichtshof den Grundrechtsschutz in jedem Einzelfall für das gesamte Gebiet der Europäischen Gemeinschaften garantiert, das Bundesverfassungsgericht sich deshalb auf eine generelle Gewährleistung der unabdingbaren Grundrechtsstandards [...] beschränken kann."

40 Classic on the conceptual structure of delegation Triepel, H., D elegation und Mandat im öffentlichen Recht (Stuttgart: Kohlhammer, 1942).

41 This is why the European Court of Human Rights recently has held that the fundamental rights of the European Convention on Human Rights apply to secondary law of the European Union qua the participation of Member States governments in the Council of Ministers, ECtHR 18.2.1999, Case 24833/94, R 32 Matthews. This is how the German Bundesverfassungsgericht brought foreign private law under constitutional control, if autonomous German conflict of laws rules oblige German courts to apply such rules, BVerfGE 31, 58 Spanier.

Comprehensive Engel, Chr., V ölk errecht als Tatbestandsmerk mal deutscher Normen (Berlin: D uncker \& Humblot, 1989), 166-171; see also Puttfarken, "Grundrechte im internationalen Rechtsraum", Recht der Internationalen W irtschaft 41 (1995): 617-627; Geefken, "Soziale G rundrechte unter Vorbehalt?", N eue Zeitschrift für A rbeitsrecht 12 (1995): 504-508.

$44 \quad$ BVerfGE $4,157,168$ and 170.

45 BVerfGE $92,26,26$ and $41 \mathrm{s.}$

$46 \quad$ BVerfGE 31, 5877.

47 BVerfG E 6, 32, 44 (restricted right to leave the country); BVerfG E 6, 290, 299 (limited protection of property lying abroad); BVerfGE 77, 1, 47 (only the conditional right of foreign spouses to immigrate). 
Respecting the properties of international relations may count as a legitimate aim for the interference. An illustrative example is provided by the decentralised mechanism for generating rules in public international law. States are not only addressed by public international law, they also generate it. If one state dislikes the contents of a rule, it will pretend that the actual contents of public international law are different. If the opponents do not protest, the mere contention can set a process in motion to change the rule. The German Constitutional Court has held that the German government should not be constitutionally prevented from playing this game ${ }^{48}$.

An act of interference with a fundamental freedom must be conducive to the legitimate aim, it must be the least intrusive measure, and it may not be overly onerous ${ }^{49}$. Given the imponderables of international relations, under the first test, the Constitutional Court finds for conduciveness if there is only some chance of success ${ }^{50}$. It accords government an exceptionally large margin of appreciation when comparing the actual interference with alternative means for reaching the same end, and when weighing the interference with the legitimate aim ${ }^{51}$. In other words, the level of protection is particularly low in international cases $^{52}$. Judicial self-restraint is exceptionally strong ${ }^{53}$.

If the international governance is not attributed to the German government, or to another entity passively legitimated by German fundamental freedoms, government may nonetheless have a constitutional duty to protect individuals from the ensuing interference with their fundamental freedoms. Government is in principle obliged to exercise its legal and factual powers in favour of individuals who are under the spell of foreign or international regulators. The classic case is diplomatic protection ${ }^{54}$. By this, public international law means the right of a country to intervene on behalf of its nationals and to ask another country to respect their internationally protected rights, such as property. But the German government is under no strict constitutional obligation to diplomatically protect its nationals abroad. They only have a litigable right that government exercises its discretion in a proper way ${ }^{55}$.

48 BVerfGE 55, 349, 366 ss. - Hess; see also BVerfGE 58, 1, 41 - Eurocontrol I; Engel, V ölkerredht als Tatbestandsmerk mal, supra note 43, 101-130 (on consensus over the interpretation of public international law rules).

49 These are the basic elements of the dogmatics of fundamental freedoms under German constitutional law. In German they read "geeignet, erforderlich, angemessen". For an overview see e.g. Ipsen, J., Staatsrecht II (G rundrechte), 3rd ed. (Neuwied: Luchterhand, 2000), R 169-182; Pieroth, B. and B. Schlink, Grundrechte (Staatsrecht II), 16th ed. (Heidelberg: C.F.Müller, 2000), R 279-297.

50 BVerfGE 92, 26, $43 \mathrm{~s}$.

51 Ibid. 44.

52 BVerfGE 59, 63, 90 ss. - Eurocontrol II.

53 BVerfGE 55, 349, $364 \mathrm{~s}$.

Leading case BVerfG E 55, 349 - Hess; more from Hofmann, supra note 34, 108-111; Klein, E., "Anspruch auf diplomatischen Schutz?", in D er diplomatische Schutz im V ölk er- und E uroparecht, eds. Ress, G. and T. Stein (BadenBaden: Nomos, 1996), 125-136. BVerfGE 55, 349, $364 \mathrm{~s}$. 
Foreign or international governance bodies are not themselves protected by the $\mathrm{G}$ erman Basic Law. They have no subjective, litigable rights. But the constitution explicitly acknowledges international openness as an objective constitutional value ${ }^{56}$. And it gives some international governance bodies special treatment. These provisions can be interpreted as early adaptations of the constitutional order to international governance. These provisions cover the European Union and other supranational public regulator ${ }^{57}$. In a broader sense, one may also interpret the provisions on international treaties ${ }^{58}$ and on customary public international law $^{59}$ as constitutional adaptations to a governance reality that partly escapes its control.

The constitutional provisions in favour of international governance have limits. It must respect the essence of fundamental freedoms, and it may not overstep the explicit boundaries for constitutional change $^{60}$. These limits can be interpreted as a constitutional obligation to mitigate the effects of international governance such that they remain within these confines. Occasionally the Constitutional Court itself engages in mitigation. The mentioned Maastricht decision is the most prominent instance ${ }^{61}$. It means that the court claims subsidiary authority to control European secondary legislation.

\section{Fundamental Freedoms and Private Governance}

Bringing private govemance under the control of fundamental freedoms would make sense. Governance is more than a mere exercise of individual freedom; it is also more than a simple exercise of economic or social power. A private governing body, at least purportedly, does not have an impact on the freedoms of others in its own interest, but in the interest of some protectees. This may justify intervention that would be unacceptable for individual purposes. But the addressees deserve no less protection from such allegedly benevolent intervention than vis-à-vis public regulators. Private governance bodies are no less likely to get the balance between the freedom of addressees and the legitimate interests of protectees wrong ${ }^{62}$. Consequently, the Federal Court of Labour Law has directly controlled the collective agreements between the unions and the employers'

56 See in particular the preamble, Art. 1 II, Art. 23-26, Art. 59 Basic Law; classic Vogel, K., Die $\mathrm{V}$ erfassungsentscheidung für die offene Staatlichk eit (Tübingen: Mohr, 1964).

$57 \quad$ Art. 23 and 24 Basic Law.

$58 \quad$ Art. 59 Basic Law.

59 Art. 25 Basic Law.

60 BVerfGE 4, 157, 170.

61 BVerfGE 89, 155.

62 See in greater detail Engel, "A Constitutional Framework for Private G overnance", Preprints aus der Max-PlandkProjek tgruppe Recht der G emeinschaftsguter B onn: 2001/ 4. 
associations against fundamental freedoms $\mathrm{s}^{63}$. The Constitutional Court has objected, however, that fundamental freedoms have no third-party effects ${ }^{64}$. It remains to be seen whether the doctrine will shift back in light of the Court decision in the Maastricht case.

If not, the entire constitutional control of private governance must be couched in terms of a governmental duty to protect the addressees from excessive intrusions into their freedom. This is particularly unsatisfactory, because some elements that help justify international governance are not present in private governance. If the international governance is not entirely foreign, it can rely on the will of the democratically elected legislator. Public international governance bodies can themselves seek some form of electoral control, and they can protect their addressees by a bill of rights.

There is, however, one difference that points in the opposite direction. Private governance bodies are themselves constitutionally protected. They have a litigable right, which they can direct against governmental intrusions into their autonomy. The distinction between individual freedom and regulatory autonomy is not yet established doctrine, however. It is a way of adapting the $\mathrm{G}$ erman constitution to the reality of systems autonomy ${ }^{65}$.

The other two constitutional strategies are even less explicit with respect to private governance. There is a great reluctance to intervene into the governing activities of the unions and the employers' associations. One may interpret this as an instance of encapsulation. So far constitutional jurisprudence has not combated private governance, but ignored it; or the parties have managed to deprive the court of the opportunity to speak to the issue.

\section{Fundamental Freedoms and Private Transnational Governance}

The international and the private elements are combined in private transnational governance. This is not hybrid governance, nota bene. The international element is purely private. There does not seem to be constitutional jurisprudence on this type of governance. The treatment should start with the principles developed for private national governance. At each step it should ask whether the international element makes a decisive difference.

63 BAGE 1, 185, 193.

64 Consequently, the Federal Court for Labour Law gave in, BAGE 52, 88, $97 \mathrm{~s}$.

65 More from Engel, Constitutional Framework, supra note 62. 
Suppose private national governance can be directly controlled by the German fundamental freedoms: does that still hold if the governing body has only some German members; if it only exercises governance activities within Germany, or toward German nationals; if it is only the functional equivalent for earlier $\mathrm{G}$ erman regulation? Is the duty to protect $\mathrm{Germans}$ or inhabitants of the country from private governance weaker if it is international in one of these senses? Can the German government invoke the exceptionally large margin of discretion for diplomatic protection? D oes the litigable right to autonomy, or at least the objective constitutional value behind it, extend to private international governance? Is protection even stronger than in domestic cases, because the general constitutional value judgement in favour of international openness applies to purely private governance as well?

\section{Fundamental Freedoms and Hybrid Governance}

Hybrid governance mixes the public and the private element. Hybrid international governance also mixes the national and the international element. The constitutional effects of these mixtures are still largely unclear. The foregoing offers a blueprint for dealing with them in the constitution. The treatment is again confined to fundamental freedoms.

It is easier to justify the direct application of fundamental freedoms to hybrid governance than to pure private governance. In principle, there is no problem with third effects, since the government is formally involved. But the problem re-enters the scene through the backdoor. Is one small public element enough to attribute the whole regulatory activity to government? Or can only this element be directly constitutionally controlled? If one in principle decides for the latter, one is again faced with the problem of third effects. It is, however, easier to opt for this solution in hybrid cases. They are closer to the logic of the Maastricht case.

The "closer to" principle can have two effects. One is straightforward. The other less so. One may ask whether the hybrid activity can profit from this principle as an exceptional justification of results that would otherwise be unconstitutional. But one may also ask whether the formation of a hybrid (international) governance body could not itself be interpreted as a tool for reserving as much influence for the German constitution as possible.

The hybrid character makes the ordinary treatment of governance under the fundamental freedoms ambivalent. D oes the public (national) element mean that the governance activities can profit from 
the direct democratic legitimacy of the $G$ erman government? D oes the private element mean that they can profit from the constitutional protection of autonomy? Do the limitations to the fundamental freedoms of the addressees thus accumulate? $\mathrm{Or}$, on the contrary, is the constitutional standard particularly strict, since autonomy is tainted by the public element, and democratic legitimacy by the private element? Is the constitution thus biased in favour of adaptation or in favour of mitigation?

* Helpful comments by Florian Becker, Adrienne Héritier, Dirk Lehmkuhl and the audience of a workshop at the European University Institute in Florence, research assistance by Christian Schmies and the linguistic trimming of the paper by Darrell Arnold are gratefully acknowledged. 